\title{
A IRONIA ROMÂNTICA EM MACHADO DE ASSIS: UMA
} ABORDAGEM SOBRE A ESCRAVIDÃO

\section{ROMANTICAL IRONY IN SHORT STORIES OF MACHADO DE ASSIS: AN APPROACH ABOUT SLAVERY}

\author{
Márcio de Araújo Melo ${ }^{1}$ \\ Marina Rodrigues de Oliveira ${ }^{2}$
}

\section{RESUMO}

Machado de Assis tornou-se conhecido, principalmente, por romances como Memórias póstumas de Brás Cubas (1881) e Dom Casmurro (1899), nos quais apresenta, por meio, sobretudo, da ironia, fortes críticas à sociedade brasileira do século XIX. Nos contos deu-se o mesmo, particularmente naqueles cujo foco foi a representação do sistema escravocrata, aspecto, às vezes, pouco abordado pela Crítica Literária que, por muito tempo, através de seus estudiosos, afirmou que o referido escritor Realista foi indiferente ou acrítico ao tema aqui em questão. Visando elucidar as considerações já feitas, iremos abordar o conto machadiano Virginius (1864), sob a perspectiva estilística, partindo do conceito de ironia romântica, abordando em que consiste esta categoria e como a mesma se relaciona ao corpus aqui selecionado.

PALAVRAS-CHAVE: Escravidão. Contos. Machado de Assis

\begin{abstract}
Machado de Assis is knowned for the novels Memórias póstumas de Brás Cubas (1881) and Dom Casmurro (1889), which has, using irony, strong critiques to brazilian society of nineteeth century. In the short stories, we can see the same stylistic trace, mainly in these that has a representation of slavery system, theme that did not many studies of Literature Criticism, once that their studious asseverates that the Brazilian writer was apathical or uncritical in relation of the present subject. This article has, as objective, to explain the studies that had been done, boarding the short story Virginius (1864) for the perspective of romantical irony.
\end{abstract}

KEY-WORDS: Slavery. Short story. Machado de Assis.

\footnotetext{
${ }^{1}$ Doutor em Estudos Literários pela Universidade Federal de Minas Gerais (2006). Professor adjunto II da Universidade Federal do Tocantins. Coordenador do Programa de Pós-Graduação em Letras: ensino de língua e literatura. Professor do ProfLetras Membro do GT/Anpoll Literatura e ensino. Primeiro secretário do GellNorte. 2 Professora do Instituto Federal de Ciência e Tecnologia do Tocantins - Campus de Porto Nacional. Doutoranda do Programa de Pós-graduação em Letras: ensino de língua e literatura - Campus universitário de Araguaína/UFT. Mestre em Letras pela Universidade Federal da Paraíba.
} 


\section{PERCURSO HISTÓRICO DA IRONIA: DA ANTIGUIDADE CLÁSSICA À IDADE CONTEMPORÂNEA.}

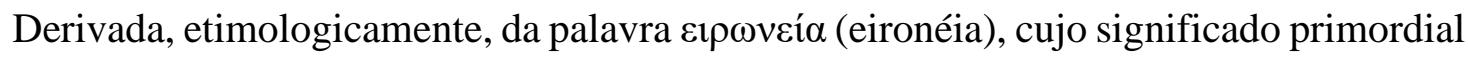
remete à ideia de "ignorância fingida", "dissimulação", "reticência"3, a ironia tem sua "origem" na Grécia Antiga, sendo abordada, dentre outros, por filósofos como Sócrates e Aristóteles. Porém, devido às limitações desse trabalho, o percurso histórico sobre a ironia irá se centrar na ironia romântica, textualizada tanto na Literatura Inglesa do século XIX, quanto na machadiana, visando estabelecer possíveis relações entre ambas, dado que o escritor Realista, além de ter lido as obras escritas por autores que utilizaram tal recurso estilístico, a exemplo de Laurence Sterne, Fielding e Thackeray, também assimilou e utilizou alguns dos traços constituintes da referida modalidade, a exemplo da junção de contrastes (realidade / ilusão, sonho / realidade) e da percepção do leitor a respeito destes.

O termo "ironia" aparece, na língua inglesa, na Inglaterra do século XVI e, posteriormente, no século XVII, se difunde, nas obras de dois escritores, John Dryden e Anthony Ashley Cooper Shaftesburry, inicialmente por meio de sinônimos, como escárnio, zombaria, sarcasmo, evoluindo, posteriormente, para o conceito de uma figura estilística que transmitia uma ideia contrária à realmente desejada, até chegar, em Shaftesbury, à concepção de "ironia suave", que, conforme saliente Muecke, em Ironia e irônico (1995, p. 32-3), é definida como “(...) uma maneira irônica acomodatícia e amigável (embora não despida de escárnio) externamente e serena e reservada internamente".

A introdução da categoria "ironia suave", por Shaftesbury, vai permitir o desencadeamento de uma nova série de análises, dentre as quais vai se destacar a de Fielding:

[...] Em 1748, Fielding deu ao termo [ironia] uma outra aplicação nova, empregandoa como a estratégia satírica (...) de inventar ou apresentar uma personagem idiota que defende ineptamente e retrata inconscientemente o ponto de vista que o autor deseja condenar. Esta 'ironia autotraidora', pelo que sei, não foi reconhecida explicitamente de novo antes do século XIX. (MUECKE, 1995, p. 33-4)

Percebe-se, pois, que o século XVIII forneceu novas perspectivas para o estudo da ironia, que passou de um recurso estilístico cujo objetivo era servir de matéria para o engano a

\footnotetext{
${ }^{3}$ Conforme assinalam os estudos de Niccola Abbagnano (Dicionário de Filosofia, 2007), Édouard des Places e o Dictionnaire Bailly.
} 
uma estratégia satírica. Com essa última finalidade, a ironia foi empregada por autores como Laurence Sterne, Diderot e Rabelais, que, em suas obras, fizeram uso de tal recurso estilístico para desconstruir a ideologia teológica dominante na época e, ainda, conseguiram imprimir à literatura uma nova visão, conforme assinala Sonia Brayner (1979), em Labirinto do espaço romanesco.

Essa concepção da ironia como desconstrução e crítica à sociedade e literatura vigentes será aprofundada no século posterior, o XIX, com o advento, no campo literário, da ironia romântica e no campo dos estudos críticos, com as contribuições de intelectuais como Fichte, os irmãos Schlegel (Friedrich e A.W.), Hegel e Heine. Johan Gottlieb Fichte considera a ironia como fruto de uma segunda potência da subjetividade, visão esta herdada de Kant e que se contrapõe à socrática, conforme é demonstrado em Kierkegaard:

[...] Se a ironia é pois uma determinação da subjetividade, então veremos em seguida a necessidade de duas formas de aparição deste conceito; e a realidade ajuntou um nome a ambas. A primeira forma é naturalmente aquela na qual a subjetividade pela primeira vez fez valer seu direito na história universal. Aqui temos Sócrates, quer dizer, com isso nos é assinalado onde temos de procurar o conceito em sua aparição histórica. Quando, porém, a subjetividade se anunciou no mundo, não voltou a desaparecer sem deixar vestígio, o mundo não recaiu na forma anterior do desenvolvimento, muito pelo contrário, o antigo desapareceu e tudo se tornou novo. Se doravante deve ser possível que se mostre uma nova forma de aparição da ironia, isso tem de acontecer de maneira que a subjetividade se faça valer em uma forma ainda mais alta. Tem de existir uma segunda potência da subjetividade, uma subjetividade da subjetividade, correspondente à reflexão da reflexão. Com isso estamos novamente orientados historicamente, somos com efeito reportados ao desenvolvimento que a filosofia moderna experimentou em Kant e que se completou em Fichte, e ainda mais proximamente aos pontos de vista que após Fichte fizeram valer a subjetividade elevada à segunda potência [...]. (1991, p. 212-3)

Após Fichte, a ironia teve, dentre outros, estudiosos como os Schelegel, Karl Solger, Connop Thirlwall, Heine, Hegel e Lausberg, cujos princípios serão vistos a seguir. A.W. Schlegel apresenta uma visão que é análoga à dos pensadores gregos, retomando, dessa forma, os princípios enunciados por Sócrates e Platão, por meio da concepção de ironia enquanto sátira, conforme é assinalado por Muecke (1995). Já Friedrich Schlegel introduz uma concepção de ironia enquanto processo que passaria de ativo para passivo, no qual o sujeito de enunciador se transforma em vítima, muitas vezes não apenas de outra pessoa, mas também de situações adversas (MUECKE, 1995)

Hegel refutará os preceitos irônicos dos irmãos Schlegel, chegando a confrontá-los, conforme assinala Kierkegaard:

[...] o fato de Hegel ter desdenhado esta forma de ironia que lhe estava mais próxima prejudicou, naturalmente, sua concepção do conceito (Hans Opfattelse af Begrebet). 
Daí porque não ganhamos uma verdadeira análise, mas em compensação Schlegel sempre ganha uma boa sova. Com isso não se quer dizer, de modo nenhum, que Hegel não tenha razão contra os irmãos Schlegel, e que a ironia da dupla Schlegel e Schlegel não tenha sido um desvio muito grave; e também com isso não se quer negar que Hegel tenha contribuído proveitosamente pela seriedade com que se opõe a qualquer isolação, uma seriedade que faz com que se possa ler muitas de suas análises com bastante edificação e reconforto. Por outro lado, não se pode omitir que Hegel, ao se voltar unilateralmente contra a ironia pós-fichteana, deixou de perceber a verdade da ironia, e ao identificar toda ironia com aquela, foi injusto com a ironia. Logo que Hegel enuncia a palavra ironia, imediatamente se impregna de uma certa exasperação. No seu devido lugar, deve ser esclarecido em que consiste o errôneo e injustificado na ironia de Schlegel, bem como o mérito de Hegel em relação a isto. (1991, p. 22930)

A postura de Hegel, portanto, é considerada bastante dual, uma vez que, ao mesmo tempo em que contribui para a conceituação da ironia - no momento em que aponta os pontos falhos da teoria dos Schlegel -, também acaba por cometer alguns equívocos, como quando delimita o conceito de tal recurso estilístico apenas à compreensão apresentada por Fichte, e, com isso, desconsidera outras de igual valia, a exemplo das apresentadas pelos filósofos gregos. Karl Solger, filósofo contemporâneo de Hegel, abordará a ironia sob a perspectiva da negatividade infinita absoluta, assim definida por Kierkegaard:

[...] Ela é negatividade, pois apenas nega; ela é infinita, pois não nega este ou aquele fenômeno; ela é absoluta, pois aquilo, por força de que ela nega, é um mais alto, que contudo não é. A ironia não estabelece nada; pois aquilo que deve estabelecer está atrás dela. (1991, p.226-7)

Tal visão será bastante criticada, em outra passagem de $O$ conceito de ironia constantemente referido a Sócrates, por Kierkegaard (1991, p. 264-5), por este acreditar que Solger havia se perdido em meio à teoria que propunha, considerando-o como uma vítima de Hegel, devido ao fato de ambos verem a ironia sob uma perspectiva que, segundo Kierkegaard, privilegiava a completa nulidade, o que implicaria, particularmente, no caso de Solger, uma ironia como um momento especulativo (KIERKEGAARD, 1991)

Posteriormente aos estudos dos irmãos Schlegel, de Solger e de Hegel, destacam-se os de Heine, que estuda a ironia partindo do duplo caráter que atribui a esta, simultaneamente autoprotetor e niilista, embora considere a romântica como a categoria mais legítima:

Para Heine, Baudelaire, Nietzsche e Thomas Mann, a ironia é antes de tudo Ironia Romântica, mas Heine também tem consciência da função autoprotetora da ironia, uma consciência que se reporta ao retrato que Teofrasto fez do eiron e antegoza algumas objeções do século XX à ironia. Onde a 'ironia universal do mundo', de Hegel, era dialética, e negativa tão-somente dentro de uma progressão mais ampla [...] a de Heine era niilista [...]. (MUECKE, 1995, p.47). 
A ironia romântica, à qual Heine se refere, tem origem na Alemanha do final do século XVIII, conforme assinala Brayner:

\begin{abstract}
Surgindo desse levedar histórico, a especulação intelectual se desenvolve na meditação dos valores nascentes de mudança e dinamismo, tomados como sintomas positivos da nova civilização. Simultaneamente, o paradoxo e a contradição das condições humanas e da própria natureza do homem são admitidos na prática e na teoria da arte, sem pretensão de serem resolvidos com apenas uma resposta metafísica. O despertar da consciência do artista lhe faz mais presente e aguda a dualidade entre a mente e o mundo, entre o Eu e o não-Eu e tende a se polarizar nos opostos: a finitude do homem frente ao mundo, cujas possibilidades totais ele não alcançará com seu conhecimento. A ironia que emerge desse corpus literário é o resultado da soma de inúmeros fatores tais como o individualismo romântico, o conflito entre ilusão e realidade, as limitações do Eu, a contradição, sempre presente, entre liberdade e necessidade, espírito e matéria, vida e morte. Para Friedrich Schlegel, um dos primeiros e mais importantes teóricos do assunto, a reconciliação dos contrários não é uma questão de síntese mas uma aquisição da ironia[...] (1979, p. 101)
\end{abstract}

A ironia romântica será, dessa forma, a representação, na arte, dos contrastes, que já existiam no contexto histórico do século XVIII, época, que, segundo Lélia Pereira Duarte, em Ironia e humor na literatura (2006, p. 141), marca o paradoxo entre a valorização do indivíduo e a massificação deste, pela sociedade burguesa, entre a importância da atividade artística e a valorização do capital financeiro. Para representar essa realidade ambivalente, na qual havia "reconciliação dos contrários", como denomina Schlegel, a ironia romântica, na Literatura, fará uso de inúmeros artifícios, assim assinalados por Duarte:

eduplicação, espelhamento, fragmentação, mascarada, inversão, autoparódia, multiplicação de papéis representados, jogo e parábase são artifícios da obra construída com a ironia romântica, em que o autor se mostra constantemente por trás de suas personagens, pois o objetivo é desfazer a ilusão da representação, contradizer o espírito de seriedade da obra. Esta não será assim a representação de algo exterior a si, mas algo que se faz diante do leitor/espectador, essencial para a existência da obra; o narrador/autor pode contar uma história, a história que quiser, conduzi-la como lhe aprouver, porque só ele a conhece (ou só ele pode inventá-la). Paradoxalmente, porém, só o pode fazer porque há quem o entenda, quem acredite nesse saber, quem se disponha a entrar nessa comunicação. (2006, p. 42-3)

É dentro dessa nova perspectiva, que, segundo Duarte (2006, p.42), a obra de arte será vista como autônoma. Com isso, nota-se o trabalho do artista, aspecto este também observado por Lukács, conforme observa Muecke:

A ironia que Lukács considera a 'mentalidade normativa do romance' é a Ironia Romântica. [...] a Ironia Romântica, como programa artístico, tem um duplo objetivo: pela incorporação da autoconsciência do artista, imbuir a obra criada (que como tal pode apenas ser limitada e parcial) da dinâmica do processo criativo, e ao mesmo tempo mas ao contrário, inventar uma forma de exprimir esta ilusão artística de autocriatividade [...].(1995, p. 119) 
A concepção de ironia romântica de Lukács se assemelha a de Schlegel, porém será questionada por Hegel, para quem a arte teria de ter um caráter moral:

\begin{abstract}
Para Schlegel e para a ironia romântica, a verdadeira arte estará desvinculada de valores morais e representa o reconhecimento do artista de que é impossível a realização de seu desejo do absoluto, dadas as suas limitações. O autor relaciona a dialética irônica com as duas polaridades do pensamento idealista - finitude e infinitude, criação e negação de si - e revela sua inclinação por uma ironia capaz de absorver todas as outras a partir da valorização do fragmento e da relatividade. Na sua teoria estética, a ironia é uma resposta à irrealizabilidade do absoluto, visto como tangível presença para a consciência. É sintomático que essa perspectiva estética schlegeliana tenha sido severamente criticada por Hegel, cujo idealismo, marcado pelos princípios da fenomenologia, valoriza a representação como a tarefa original da expressão artística, vista como um degrau para se chegar ao absoluto. É que, para Hegel, a arte tem de ser moral, sendo a linguagem mediadora entre as representações interiores e exteriores (DUARTE, 2006, p. 43).
\end{abstract}

A incapacidade de realizar o absoluto e o contraste entre finitude e infinitude conduzem a outro aspecto constituinte da ironia romântica, o isolamento do homem, causado pelo fato deste se tornar objeto de si próprio, sendo privado das faculdades de poder e agir, que irão de encontro ao caráter cindindo e finito do mundo, conforme destaca Szondi (1991, p. 109 apud Beth Brait, 2008, p. 34), em Ironia em perspectiva polifônica.

Berel Lang, no artigo The limits of irony, destaca que a ironia romântica trouxe à tona uma nova preocupação, a necessidade de se definir o que seria o não irônico:

Para a ironia romântica, que [,] dessa forma [,] encontra a evidência para o que reivindica resumir na relação entre arte e mundo, o problema persiste se qualquer arte poderia ser não irônica. E isso nada vale [,] uma vez que os teóricos [,] que anteriormente não se identificavam com os românticos, muitas vezes rejeitaram essa possibilidade. A linha de raciocínio aqui é atraente, mas enganosamente simples: porque a arte é uma redescrição ou revisão - o que estende a contradição - do mundo como dado, seu caráter intrinsecamente irônico (a afirmação continua) é inevitável. Então, um crítico tão conservador como Northop Frye chega à mesma conclusão geral: 'A estrutura literária é irônica', ele escreve, 'porque o que ela diz' é sempre diferente em classe e gênero do 'que ela significa'4(1996, p. 575)

\footnotetext{
${ }^{4}$ Tradução livre da seguinte citação: "[...] For romantic irony, which thus finds the evidence for its claims epitomized in the relation between art and world, the question persists of whether any art could be nonironic. And it is worth nothing that also theorists not otherwise identified with the romantics have often rejected this possibility. The line of argument here is engagingly but deceptively simple: because art is a redescription or revision - to that extent a denial - of the world as given, its intrinsically ironic character (the claim goes) is inescapable. Thus, so conservative a critic as Northrop Frye arrives at the same broad conclusion: 'The literary structure is ironic', he writes, 'because 'what it says' is always different in kind or degree from 'what it means'".
} 
A afirmação de Lang serve para reforçar o caráter paradoxal do qual a ironia romântica é constituída, característica que, somada ao desmascaramento da arte e da contestação das regras, contribuiu para que o referido tropo transcendesse o século XVIII e promovesse novas dimensões à arte moderna, conforme é afirmado em Brait:

[...] é necessário esclarecer que, além do caráter quase religioso que a reveste, no
sentido de desfazer as aparências do mundo filisteu, aí estão assinalados outros dois
aspectos que, sendo característicos da ironia romântica, podem ser tomados como
antecipadores, ou mesmo precursores, de várias dimensões da arte moderna: a) a
utilização da ironia como forma de cortar a ilusão criada pela própria obra de arte; b)
a importância da ironia romântica em seu trabalho de abolir a coerência, abalar as
regras da lógica, contestar o domínio do racional.. (2008, p. 39)

Dentre as obras literárias que já apresentam traços da ironia romântica, Schlegel cita Dom Quixote (Cervantes), Tristam Shandy (Laurence Sterne) e Jacques, le fataliste (Diderot), conforme assinala Muecke (1995).

A ironia romântica será aqui priorizada, uma vez que se observam, nos contos machadianos aqui em análise, algumas das características de tal modalidade, a exemplo do humor, da presença de uma ironia que assinala para a noção entre realidade e ilusão e da ambiguidade discursiva, que permitem perceber a representação do escravo sob a perspectiva que a sociedade patriarcal tinha deste.

\section{VIRGINIUS (1864): O EMBRIÃO DA REPRESENTAÇÃO ESCRAVOCRATA}

Virginius, primeiro dos contos aqui analisados a abordar a representação do sistema escravocrata, destaca-se, ainda, pela presença de um narrador personagem anônimo, que irá se relacionar com duas das personagens mais importantes da história, Pio, ou Pai de Todos, e Julião. O primeiro é um rico fazendeiro, cujo apelido remonta a uma imagem bíblica bastante contundente, que, paradoxalmente, apesar da índole nobre, perpetua o sistema servil; o segundo, um empregado daquele. Apesar das diferenças sociais e raciais existentes - uma vez que Pio é branco e Julião, negro -, o relacionamento de ambos é bastante amigável, fato que se comprova pela estreita convivência, na infância, entre seus respectivos filhos, Carlos e Elisa.

Tal relação, entretanto, sofrerá grandes mudanças, quando, após uma longa separação, Carlos, já adulto, volta à fazenda do pai e começa a assediar sexualmente Elisa, que o recusa, atitude desencadeadora do clímax narrativo, cuja análise será feita posteriormente. Antes, convém aprofundar alguns aspectos relativos ao enredo. 
O conto é iniciado com o recebimento de uma carta pelo advogado-narrador, cujo nome é desconhecido contendo um bilhete, no qual seu cliente, cuja identidade até então também é ignorada, chama-o para defender uma causa, em uma vila próxima, com dinheiro para despesas e honorários.

Chegando à vila indicada na carta, e após conversar com um ex-colega, também advogado e residente na localidade, o advogado-narrador tem revelada a identidade de seu cliente: tratava-se de Pio, também conhecido como Pai de todos, um poderoso fazendeiro da região. Em meio à conversa, um dos empregados de Pio passa em frente à casa do amigo do advogado "visitante". Quando este pergunta ao amigo se o negro que passara era escravo do poderoso fazendeiro, tem a seguinte resposta:

\begin{abstract}
- Escravo é o nome que se dá; mas Pio não tem escravos, tem amigos. Olham-no todos como se fora um Deus. É que em parte alguma houve nunca mais brando e cordial tratamento a homens escravizados. Nenhum dos instrumentos de ignomínia que por aí se aplicam para corrigi-los existem na fazenda de Pio. Culpa capital ninguém comete entre os negros da fazenda; a alguma falta venial que haja, Pio aplica apenas uma repreensão tão cordial e tão amiga, que acaba por fazer chorar o delinquente. Ouve mais: Pio estabeleceu entre os seus escravos uma espécie de concurso que permite a um certo número libertar-se todos os anos. Acreditarás tu que lhes é indiferente viver livres ou escravos na fazenda, e que esse estímulo não decide nenhum deles, sendo que, por natural impulso, todos se portam dignos de elogios? (MACHADO DE ASSIS, 1998, p. 79).
\end{abstract}

Observa-se, no trecho acima, o primeiro momento no qual a ironia romântica se manifesta: na fala do amigo do advogado de Pio, percebe-se um claro contraste discursivo característica que é integrante do referido tipo de ironia - uma vez que é afirmado, inicialmente, que o fazendeiro não possui escravos, mas amigos, e, logo em seguida, é dito que Pio liberta, anualmente, por meio de um concurso, alguns escravos.

Essa concepção humanizada com a qual Pio trata seus cativos, que se diferencia da geralmente destinada aos mesmos, parece, aos advogados, não apenas distinta, mas beirando à anormalidade, fato observado, sobretudo, quando é afirmado que a diferença entre o cativeiro e a liberdade, para os servos do fazendeiro, não era sentida. A opinião dos advogados, em relação à alforria, constitui-se como um segundo momento no qual a ironia romântica faz-se presente, uma vez que conforme já foi visto e assinalado no capítulo um, as diferenças entre o escravo e o liberto eram bastante significativas.

Julião, um dos personagens negros do conto, é, segundo Natascha Machado Kresh, no artigo "O escravo e o protegido: percepção do trabalho servil em 'Virginius"” (2010, p. 155), um trabalhador livre, e não um escravo, uma vez que possui propriedade própria, em um terreno 
fora da área que pertence a Pio, e, além disso, quando é preso, pelo crime de assassinato, responde em juízo, privilégio que, segundo Kresh, só era destinado aos cidadãos.

A interpretação de Kresh, apesar de ter validade, deixa de considerar dois aspectos: o primeiro é que a narrativa machadiana não apresenta Julião como um homem livre, mas como um agregado de Pio, conforme fica assinalado no trecho abaixo:

\begin{abstract}
Julião fora um daqueles a quem a alma caridosa de Pio dera sustento e trabalho. Suas boas qualidades, a gratidão, o amor, o respeito com quem falava e adorava o protetor, não ficaram sem uma paga valiosa. Pio, no fim de certo tempo, deu a Julião um sítio que ficava pouco distante da fazenda. Para lá fora morar Julião com uma filha menor, cuja mãe morrera em conseqüência dos acontecimentos que levaram Julião a recorrer à proteção do fazendeiro. (MACHADO DE ASSIS, 1998, p. 81).
\end{abstract}

O segundo aspecto, que está relacionado ao primeiro, é que, mesmo se considerando Julião como um homem-livre, é conveniente lembrar que, na época, muitos negros libertos continuavam a morar e a servir seus senhores, mantendo as mesmas relações senhor / escravo de outrora, caso este em que está inserido o personagem e sua filha, Elisa.

Elisa é a outra personagem negra do conto, cuja trajetória é entremeada tanto pela ironia romântica, quando pela exploração sexual. No conto, Elisa mora com seu pai, Julião, trabalhando nas atividades domésticas do sítio onde vive, sendo descrita, na narrativa, como uma jovem bela, de boa índole, reunindo, dessa forma, atributos que a faziam atraente, não se enquadrando nas representações estereotipadas, presentes na Literatura, a respeito da mulher negra, a exemplo da amante lascívia, da feiticeira, da mucama infiel, dentre outras visões negativas 5 .

Jovem e virgem, Elisa vai ser estuprada por Carlos, que se aproveita da ausência de Julião, invade o sítio deste, acompanhado de alguns capangas, amarra e amordaça uma parente do dono da casa que se encontrava no ambiente. Este momento é bastante simbólico, uma vez que representa, por meio do filho de Pio, a imagem da ideologia patriarcal, que via a mulher negra como um mero objeto para a satisfação do desejo sexual, ainda que não consentido:

Era já perto da noite. Julião caminhava vagarosamente, pensando no que lhe faltaria ainda para completar o pecúlio de sua filha. Nessas divagações, não reparou que anoitecera. Quando deu por si, ainda se achava umas boas braças de casa. Apressou o passo. Quando se achava mais perto, ouviu uns gritos sufocados. Deitou a correr e penetrou no terreiro que circundava a casa. Todas as janelas estavam fechadas; mas os gritos continuavam cada vez mais angustiosos. Um vulto passou-lhe pela frente e

\footnotetext{
${ }^{5}$ A respeito de tais e outras representações do negro, na Literatura Brasileira, ver a obra "O negro na Literatura Brasileira", de Raymond S. Sayers (1958).
} 
dirigiu-se para os fundos. Julião quis segui-lo; mas os gritos eram muitos, e de sua filha. Com uma força difícil de crer em corpo tão pouco robusto, conseguiu abrir uma das janelas. Saltou, e eis o que viu: A parenta que convidara a tomar conta da casa estava no chão, atada, amordaçada, exausta. Uma cadeira quebrada, outras em desordem (...). (MACHADO DE ASSIS, 1998, p. 84-5).

Esse momento da narrativa não apenas deflagra a ideia de assalto sobre a jovem Elisa, como também demonstra a anulação da identidade da personagem feminina principal da obra, que em momento algum se mostra como uma mulher capaz de reagir ao constante assédio do qual acaba sendo uma vítima fatal, condição semelhante à de outra personagem machadiana, Eugênia, jovem pobre e coxa, que em Memórias póstumas de Brás Cubas, após ter um romance com o narrador-personagem, acaba sendo rejeitada por este. No tocante, particularmente, à condição de Elisa, Krech faz a seguinte análise:

O papel de Elisa no conto é complicado. Elisa, além de ser a única personagem
feminina em 'Virginius', é, como referido acima, o ponto de convergência da história;
ela incorpora o único motivo pelo qual o ocorrido torna-se digno de relato. Ao
contrário do que se espera de personagem tão relevante, Elisa praticamente não exerce
ação alguma no conto todo. Mais além, Elisa não tem direito a ação. Não tem o direito
de expor as suas ideias na trama, pois praticamente não lhe é dada a palavra. Não pode
ser mulher sem ser cobiçada, ou melhor, assediada sexualmente pelo filho do patrão.
Nem tem o direito de viver, se essa vida não for honrosa. Elisa é uma marionete num
mundo de homens: muda, estática, passiva. Lembremo-nos de que o público alvo de
'Virginius', principais leitores do Jornal das Famílias, eram mulheres. Como já se
viu, Machado provavelmente não desejava ser relacionado de forma direta a uma
polêmica; isso porém não significa que não polemizasse a seu modo. Talvez aspirasse
sensibilizar os corações femininos de forma mais sutil. Procurava a simpatia de suas
leitoras para com Elisa-mulher e não, necessariamente, para com Elisa-mulata. (2010,
p. 157)

Após perceber que sua filha havia sido estuprada, Julião, para "salvar a honra" da mesma, acaba a assassinando. Carlos, que minutos antes deixara o local do cativeiro, chega com a polícia, que acaba prendendo o pai da jovem, enquanto o filho de Pio consegue, nesse momento, sair impune. A morte de Elisa, entretanto, não se dá de forma abrupta: Julião, antes de ter a casa invadida, fica sabendo, por meio da filha, que Carlos a estava assediando e decide conversar com o rapaz, que garante que irá respeitar a jovem "(...) como se fosse morta" (MACHADO DE ASSIS, 1998, p. 84). Em tal frase, se percebe, mais uma vez, a presença da ironia romântica, desta vez, explicitando a ambiguidade proposital do discurso, uma vez que as intenções de Carlos, conforme vai sendo assinalado, ao longo da construção do perfil da personagem, remetem ao oposto do que é prometido, tornando-o falso. 
A narrativa de Machado de Assis retoma um outro texto, da Literatura Greco-Latina, a história de Virginius, cuja filha Virgínia, desperta interesse de um magistrado romano, Ápio Cláudio, fato observado nas análises de José Aderaldo Castello, em Realidade e ilusão em Machado de Assis (2008, p. 94) e Eduardo Melo França, em Ruptura ou amadurecimento? Uma análise dos primeiros contos de Machado de Assis (2008, p. 144). Virgínia, entretanto, não corresponde ao sentimento de Ápio Cláudio, que procura se vingar da jovem e do seu pai, tomando-a como escrava, atitude que acaba sendo impedida por Virginius, que, para não ver a filha presa à servidão, a assassina.

No conto machadiano, a história de Virginius é "transposta" para o contexto histórico do Brasil escravagista: Virginius torna-se Julião, Virgínia, Elisa e Ápio Cláudio, Carlos. O conto Virginius, entretanto, não deve ser visto como uma mera representação do referido momento, no qual está inserido, mas sob uma perspectiva mais ampla, conforme demonstra França:

\begin{abstract}
Não podemos negar que Virginius apresenta elementos que retratam a condição social do Brasil do séc. XIX. Contudo, reduzir o seu sentido a uma suposta intenção de Machado em simplesmente tê-lo concebido como uma peça de denúncia social contra as consequências de um regime escravocrata, é não perceber que já em 1864 Machado possuía esse profundo senso de dialética entre o clássico e o novo, o universal e o particular, a história e a psicóloga. Ao mesmo tempo em que a tentativa de desrespeito de Carlos em relação à Elisa pode ser lida como supostamente motivada por essa pulsão sádica, egoísta e violenta do ser humano, também não devemos perder de vista que será somente através das possibilidades oferecidas pelo seu meio, ou seja, o regime patriarcal, escravocrata e a condição privilegiada dos senhores de escravos no Brasil dos oitocentos, que essa pulsão encontrará a possibilidade de ser posta em prática [...] (2008, p. 146-7)
\end{abstract}

Ao "dialogar" com a Literatura Greco-Latina, Machado de Assis, em Virginius, representa, ainda que de forma "embrionária", a escravidão e suas mazelas, destacando, principalmente, a violência contra a mulher negra, por meio da personagem Elisa, que, conforme foi visto, não representa o estereótipo da escrava lascívia, traidora, feiticeira, ou de caráter duvidoso, mas sim, o de uma jovem vitimizada pela luxúria masculina. Além disso, convém enfatizar que, embora Julião assassine a própria filha, de modo análogo ao que ocorre na narrativa de Tito Lívio, o que se observa, em Virginius, é a descrença na inocência do cativo, por parte tanto do advogado-narrador - mesmo quando fica sabendo dos reais motivos que levaram ao crime -, quanto de seu colega, como fica registrado nas seguintes passagens: 
- Não, disse-lhe [o narrador-advogado a seu colega], deixa-me saber de tudo por boca do próprio réu. Depois compararei com o que me contarás.

- É melhor. Julião é inocente...

- Inocente?

- Quase. (MACHADO DE ASSIS, 1998, p. 79).

Depois de algum silêncio disse-me [Pio ao narrador-advogado]:

- Já falou ao Julião?

- Já.

- Conhece então toda a história?

-Sei do que ele me contou.

- O que ele lhe contou é o que se passou (...). (MACHADO DE ASSIS, 1998, p. 90).

Após a inocência de Julião ser conhecida por Pio e do convencimento, por parte do advogado-narrador, da mesma, delineia-se o final de Virginius, estando representada a ironia romântica, no que diz respeito ao contraste entre possibilidade e realidade: Julião, após cumprir pena de dez anos de prisão, volta a conviver com Pio, enquanto Carlos é castigado, sendo mandado para o exército, destinos estes que, considerando o contexto social do Brasil escravocrata, e, principalmente da organização social vigente, na época, não seriam possíveis:

No momento em que escrevo estas páginas, Julião, tendo já cumprido a sentença, vive na fazenda de Pio. Pio não quis que ele voltasse ao lugar em que se dera a catástrofe, e fá-lo residir ao pé de si. [...] Quanto a Carlos, vai resgatando como pode o crime com que atentou contra a honra de uma donzela e contra a felicidade de dois pais. (MACHADO DE ASSIS, 1998, p. 92-3).

Pela data em que foi publicado o conto, 1864, e sabendo que a punição de Carlos foi o exército, subentende-se que o jovem poderia ter sido mandado como soldado para a Guerra do Paraguai, fato percebido por Krech:

Tal hipótese pode ser considerada plausível, levando-se em consideração o castigo que Pio escolheu para o filho, mandando-o ao exército: o trabalho disciplinador, a perda dos bens materiais, da posição social e um futuro de submissão. Outro aspecto interessante da punição é o fato de Carlos ter sido enviado pelo 'Pai de Todos' às tropas do sul. Por mais que narrativa se passe em meados de 1850, o conto foi publicado em 1864. Em vista disso, é deveras provável que o leitor de 'Virginius' associe o castigo com a iminente guerra entre Brasil e Paraguai. (2010, p. 154) 
Em Virginius, já se observa, por meio do uso da ironia, a crítica machadiana ao sistema escravagista, bem como à violência sofrida pela mulher negra, aspecto até então pouco observado na obra do escritor, muito embora esteja inserido na denominada "fase Romântica", fato que se evidencia pelo maniqueísmo presente na narrativa, especialmente no final. A temática presente em Virginius ganhará contornos mais densos em Mariana, conto publicado em 1871, cujo enredo, embora semelhante, tem, como principal diferença, o fato da personagem-título ser uma "cria" da casa grande, residindo lado a lado com seus senhores.

\section{CONSIDERAÇÕES FINAIS}

Este trabalho teve como objetivo estudar a ironia, enquanto recurso estilístico, na representação do escravo, no conto de Machado de Assis, Virginius (1864), objetivando decodificar uma suposta posição crítica do escritor sobre a escravidão, um aspecto que foi por muito tempo contestado por alguns estudiosos, a exemplo de Lúcia Miguel-Pereira, cuja obra, Machado de Assis: estudo crítico e biográfico, assinala o pressuposto da "apatia" machadiana, no tocante ao referido tema.

Da pesquisa, chega-se à conclusão que os textos machadianos não apenas se encontram em consonância com os acontecimentos da época, como, ainda, representam o tema da escravidão sob uma nova perspectiva, a de apresentar o negro não mais como uma personagem presa aos estereótipos vigentes (a negra feiticeira, o negro vingativo, o negro herói, a multa lascívia, etc.), mas como um ser humano, cuja história será o "fio condutor" das narrativas, posição que é observada, pela Crítica Literária, pelos estudos de Raymond S. Sayers, O negro na Literatura Brasileira (1958); José Aderaldo Castello, Realidade e ilusão em Machado de Assis, (1969); Raymundo Faoro, Machado de Assis: a pirâmide e o trapézio (1974); Roberto Schwarz, Ao vencedor as batatas (1977) e Um mestre na periferia do capitalismo (1990); John Gledson, Machado de Assis: ficção e história (1986) e Por um novo Machado de Assis: ensaios (2006); Regina Zilberman, "Um caso para o leitor pensar” (1989); Alfredo Bosi, Machado de Assis: o enigma do olhar (1999); Massaud Moisés, Machado de Assis: ficção e utopia (2001) e Alcides Villaça, "Querer, poder, precisar: 'O caso da vara”” (2006)

O enredo do conto, aqui em análise, é reforçado pela presença da ironia, cujas possíveis definições e classificações foram vistas por meio dos estudos de Kierkegaard, O conceito de ironia constantemente referido a Sócrates; D. C. Muecke, Ironia e irônico; Berel Lang, "The limits of irony" e Beth Brait, Ironia em perspectiva polifônica, que proporcionaram um 
panorama a respeito de tal figura de linguagem, que surge, inicialmente, na Antiguidade Clássica, com fins jocosos, cuja intenção era a de lograr o ouvinte, estratégia muito utilizada por nomes com Aristóteles e Sócrates; com o passar do tempo, o conceito de ironia foi visto pela perspectiva filosófica, na qual se destacaram nomes como Karl Solger e Kierkegaard. A fase mais recente sobre os estudos sobre a ironia a associa à linguística, vendo o referido tropo discursivo sob uma perspectiva dialógica, que necessita sempre da interação entre os que dela participam.

Tais mudanças, no conceito de ironia, permitiram observar não apenas o aprofundamento no estudo de tal figura de linguagem, como, também a interferência de tais perspectivas na Literatura. Juntamente à revisão conceitual, foram vistas as diversas modalidades da ironia (observável, dramática, paradoxal, etc.), tendo sido escolhidas, para análise do conto machadiano, a ironia romântica, uma vez que há, claramente, a ideia de contraste (mundo escravo x mundo senhorial) e a ironia sensu eminentori, na concepção de Kirkegaard, dado o caráter de contestação de uma realidade histórica - no caso, a escravidão - Além destas tipologias foi utilizado, também, o conceito de narrador irônico, presente, na narrativa estuda, por meio do diálogo que este estabelece com o leitor, tentando aproximá-lo do discurso ideológico que quer transmitir (no presente caso, o de opressão do escravo) e afastálo dos personagens mais importantes, os cativos.

Dessa forma, o que pôde se observar, neste trabalho, foi que Machado de Assis, diferentemente do que por muito tempo se acreditou, não foi um autor omisso ao problema da escravidão, uma vez que não apenas o abordou em seus escritos, especialmente nos contos, como, ainda, o fez mostrando, por meio da ironia e dos narradores irônicos, a opressão sofrida pelos cativos, perspectiva, até então, pouco percebida na Literatura Brasileira. É necessário, entretanto, destacar que a discussão aqui apresentada foi apenas inicial, sendo possível, a partir dela, o surgimento de outras tantas, para as quais esperamos ter apresentado a nossa contribuição.

\section{REFERÊNCIAS BIBLIOGRÁFICAS:}

ABBAGNANO, Nicola. Dicionário de filosofia. São Paulo: Martins Fontes, 2007. p. 555.

BOSI, Alfredo. Machado de Assis: o enigma do olhar. São Paulo: Ática, 1999. p. 55. 
BRAIT, Beth. Percursos e percalços no estudo da ironia. In: _. Ironia em perspectiva polifônica. 2. ed. Campinas, SP: Editora da Unicamp, 2008. p. 29; 34; 39.

BRAYNER, Sonia. Labirinto do espaço romanesco. Rio de Janeiro: Civilização Brasileira, 1979. p. 99; 101; 117.

CASTELlO, José Aderaldo. Realidade \& ilusão em Machado de Assis. 2.ed. Cotia, SP: Ateliê Editorial, 2008. p. 58-9.

DUARTE, Lélia Pereira. Ironia e humor na literatura. Belo Horizonte: Editora PUC Minas; São Paulo: Alameda, 2006. p.42-3; 43; 141.

FRANÇA, Eduardo Melo. Ruptura ou Amadurecimento? Uma análise dos primeiros contos de Machado de Assis. Recife: Ed. Universitária da UFPE, 2008. p. 144; 146-7.

GLEDSON, John. Por um novo Machado de Assis: ensaios. Vários tradutores. São Paulo: Companhia das Letras, 2006. p. 53-4.

KIERKEGAARD, S.A. O conceito de ironia constantemente referido a Sócrates. Tradução de Álvaro Luiz Montenegro Valls. Petropólis: Vozes, 1991. p. 212-3; 226-7; 229-30; 264-5; 274-5. (Coleção Pensamento Humano).

KRECH, Natascha Machado. O escravo e o protegido: percepção do trabalho servil em Virginius. In: BERNARDO, Gustavo; MICHAEL, Joachim; SCHÄFFAUER, Marckus (Orgs.). Machado de Assis e a escravidão. São Paulo: Annablume, 2010, p.151-2; 155.

LANG, Berel. The limits of irony. New Literary History, vol. 27, n. 3. p. 575, 1996.

MACHADO DE ASSIS, Joaquim Maria. Virginius. In: GLEDSON, John. Contos: uma antologia, volume I. São Paulo: Companhia das Letras, 1998. p. 79; 81; 84; 84-5; 92-3.

MUECKE, D.C. Ironia e irônico. São Paulo: Editora Perspectiva, 1995. p. 31; 32-3; 33-4; 41; $43 ; 47 ; 119$.

SCHWARZ, Roberto. As ideias fora do lugar. In:_. Ao vencedor as batatas: forma literária e processo social nos inícios do romance brasileiro. São Paulo: Duas Cidades, Ed.34, 2003.

Um mestre na periferia do capitalismo: Machado de Assis. 4. ed. São Paulo: Duas Cidades; Ed. 34, 2000, 2008. p. 128-9. 